\title{
A CONSTRUÇÃO DO CONHECIMENTO A PARTIR DA REALIDADE DO EDUCANDO
}

\author{
LA CONSTRUCCIÓN DEL CONOCIMIENTO \\ A PARTIR DE LA REALIDAD DEL EDUCANDO
}

THE CONSTRUCTION OF KNOWLEDGE FROM THE REALITY OF EDUCATION

\author{
André Luis Castro de FREITAS ${ }^{1}$ \\ Luciane Albernaz de Araujo FREITAS ${ }^{2}$
}

RESUMO: O texto possui como objetivo tecer aproximações ao pensamento de Paulo Freire, no que pese à constituição de uma relação dialética entre as práticas sociais e o conhecimento, de tal maneira que os seres humanos assumam uma postura crítica e criativa frente ao mundo do qual fazem parte. A partir de um estudo descritivo crítico, resultante de uma pesquisa de abordagem qualitativa, bibliográfica, tem-se como intenção elencar pressupostos que demonstrem, na concepção freiriana, o fazer de uma educação popular mais humana e libertadora, que não aceita o fatalismo da precariedade do ser humano exposto ao sofrimento. A investigação toma como ponto de partida as relações dialético-dialógicas freirianas imbricadas a indissociável visão entre epistemologia e política, levando em consideração as transformações desejadas no contexto vivido.

PALAVRAS-CHAVE: Diálogo. Epistemologia. Política.

RESUMEN: El texto tiene como objetivo tejer acercamientos al pensamiento de Paulo Freire en lo que pese a la constitución de una relación dialéctica entre las prácticas sociales y el conocimiento, de tal manera que los seres humanos asuman una postura crítica y creativa frente al mundo del cual forman parte. A partir de un estudio descriptivo crítico, resultante de una investigación de abordaje cualitativo, bibliográfica, se tiene como intención enlechar presupuestos que demuestren, en la concepción freiriana, el hacer de una educación popular más humana y liberadora, que no acepta el fatalismo de la precariedad del ser humano expuesto al sufrimiento. La investigación toma como punto de partida las relaciones dialéctico-dialógicas freirianas imbricadas la indisociable visión entre epistemología y política, teniendo en cuenta las transformaciones deseadas en el contexto vivido.

PALABRAS CLAVE: Diálogo. Epistemologia. Política.

${ }^{1}$ Universidade Federal do Rio Grande (FURG), Rio Grande - RS - Brasil. Professor associado. Doutor em Ciência da Computação. Mestre e Doutor em Educação. ORCID: 〈http://orcid.org/0000-0002-4566-3655>. Email:dmtalcf@furg.br.

${ }^{2}$ Instituto Federal Sul-rio-grandense (IF SUL) Pelotas - RS - Brasil. Professora do IFSUL. Mestre em Desenvolvimento Social. Doutora em Educação Ambiental. ORCID: <http://orcid.org/0000-0001-9014-0071>. E-mail: lucianel1968@gmail.com. 
ABSTRACT: The text aims to do approximations to the thought of Paulo Freire as the focus on the constitution of a dialectical relationship between social practices and knowledge, in such a way that human beings take a critical and creative stance towards the world of which they are part. From a critical descriptive study, resulting from a qualitative, bibliographical research, one has as an intention to list presuppositions that demonstrate, in the Freire's conception, the making of a popular and liberating human education that does not accept the fatalism of the precariousness of the human being exposed to suffering. The investigation takes as its starting point Freire's dialectic-dialogic relations imbricated the inseparable vision between epistemology and politics, taking into account the desired transformations in the lived context.

KEYWORDS: Dialogue. Epistemology. Politics.

\section{Considerações iniciais}

Considerando Freire (1969, 2004), em seu primeiro momento, no final dos anos sessenta, obras como Educação como prática da liberdade e Pedagogia do oprimido, o ser humano é sujeito, com atuação e intencionalidade, estando para além de um objeto do mundo ${ }^{3}$ do qual faz parte.

A proposta freiriana compreende a possibilidade da intervenção humana no mundo e como esse ser pode vir a causar modificações na realidade em que está inserido e, dessa maneira, o conceito de relações ${ }^{4}$ assume centralidade na discussão.

É pelo caminho das relações que o ser humano, no exercício de sua singularidade, constitui a pluralidade imbricada à criticidade. A captação que faz da realidade concreta e da articulação que propõe sobre o dado analisado é crítica e reflexiva e não, apenas, reflexa característica da esfera dos simples contatos.

Nas relações há uma intervenção intencional vinculada à dimensão cultural, associada à capacidade de transcender do ser humano. Para Freire, “[...] é o homem, e somente ele, capaz de transcender" (FREIRE, 1969, p. 40). A transcendência representa a possibilidade de

\footnotetext{
${ }^{3}$ Para Andreola (2010), "Freire relaciona a categoria mundo com: a natureza, cultura, história, existência, consciência, trabalho, ação transformadora, palavra e práxis, conceitos através dos quais ele tenta explicar a relação dialética: leitura do mundo - leitura da palavra, fundamento de toda a alfabetização e de toda a educação" (ANDREOLA, 2010, p. 283). Segundo o autor, para o ser humano, o mundo significa o contexto de sua existência, transformando esse contexto por sua ação.

${ }^{4} \mathrm{Na}$ obra Educação como prática da liberdade, Freire (1969) assume que as relações que o ser humano trava no e com o mundo, sejam elas pessoais, impessoais, corpóreas ou incorpóreas, apresentam um conjunto de características que estão para além dos simples contatos próprios da esfera animal. A partir desse contexto, enfatiza que há uma pluralidade nas relações entre seres humanos na medida em que esses respondem a desafios propostos e que essas respostas não se esgotam em uma padronização. "No jogo constante de suas respostas, altera-se no próprio ato de responder. Organiza-se. Escolhe a melhor resposta. Testa-se. Age. Faz tudo isso com a certeza de quem usa uma ferramenta, com a consciência de quem está diante de algo que o desafia" (FREIRE, 1969, p. 40).
}

RPGE- Revista on line de Política e Gestão Educacional, Araraquara, v.22, n.1, p. 365-380, jan./abr. 2018 DOI: $10.22633 /$ rpge.v22.n.1.2018.10707

ISSN: $1519-9029$ 
que o ser venha a refletir sobre si, sobre o mundo, na busca da compreensão pelo sentido de existir, promovendo, a possibilidade de pensar diferentes existenciais.

Nesse contexto, destacam-se os saberes envolvidos na reflexão sobre o pensar diferentes existenciais tal que se faz necessário promover tanto a valorização do conhecimento científico como o saber oriundo das experiências dos sujeitos envolvidos na relação, de maneira a considerar os saberes provenientes da realidade. Saberes esses que, em nenhum momento, podem ser vistos como inferiores ou de menor valor, mas, pelo contrário, os saberes provenientes da cultura, do dia a dia, dos seres humanos são fundamentais para a ação no contexto freiriano. Já a reflexão acontece no momento em que esses sujeitos empoderados pelo conhecimento intelectual, científico, refletem criticamente sobre a realidade.

Assim, a ação-reflexão está inserida no processo dialético freiriano quando se assume o pressuposto de que a educação ${ }^{5}$ compreende a autotransformação dos seres humanos, promovendo a postura interferente desses no contexto onde estão inseridos. Para Kronbauer (2010), a ação-reflexão freiriana “[...] designa o binômio da unidade dialética da práxis, supondo que esta seja o fazer e o saber reflexivo da ação. O saber que realimenta criticamente o fazer, cujo resultado incide novamente sobre o saber e, assim, ambos se refazem continuamente" (KRONBAUER, 2010, p. 23).

Nessas condições, a educação para Freire requer como condição indispensável uma relação dialética entre as práticas sociais e o conhecimento, de tal maneira que os sujeitos assumam uma postura crítica e criativa frente ao mundo do qual fazem parte, no intuito de que sejam capazes de se perceberem como sujeitos capacitados a escolhas e decisões.

Aproximando as ideias trabalhadas, a intencionalidade do texto, aqui proposto, é problematizar, a partir das ideias de Paulo Freire, a indissociável visão entre epistemologia e política, levando em consideração as trasnformações desejadas no contexto vivido. O texto está descrito da seguinte forma: Educação para a transformação social discute-se que o papel político da epistemologia é condição prévia para a efetivação de seu compromisso maior que visa elaborar ações que promovam o rompimento de uma visão de mundo fragmentada e acrítica; $O$ diálogo em uma educação como ato político faz-se uma retomada da relação dialógica freiriana, diálgo esse que a partir de sua dimensão ontológica possibilita a partilha entre educador e educandos tal que permite a redefinição do quadro do poder entre os sujeitos

${ }^{5} \mathrm{Na}$ obra Educação como prática da liberdade, Freire (1969) se refere ao processo de alfabetização, ao sustentar que essa "[...] não pode ser feita de cima para baixo, como uma doação ou imposição, mas de dentro para fora, pelo próprio analfabeto, apenas com a colaboração do educador” (FREIRE, 1969, p. 111). 
envolvidos; e Educação como ato político - realizam-se reflexões sobre a correlação entre a leitura de mundo e o dizer a palavra, como o desvelar a realidade, na qual o sujeito atuará sobre essa, de forma a propor transformações. Após seguem as considerações finais.

\section{Educação para a transformação social}

Retomando o pressuposto de que a proposta freiriana requer que os seres humanos sejam capazes de se perceberem como sujeitos capacitados as escolhas e decisões, a epistemologia estabelece uma unidade dialética com a política tal que permite compreender a indissociável relação entre o conhecimento científico e os saberes provenientes da realidade concreta. O conhecimento necessita ser construído a partir do contexto e, sobretudo, com o propósito de nele efetivar modificações que venham a qualificar os seres humanos oprimidos.

Dessa maneira, a epistemologia passa a ser elemento central na constituição das relações de poder, pois, por meio do conhecimento, torna-se possível compreender qual é a concepção de mundo que sustenta a vida dos diferentes grupos sociais e como essa concepção é elaborada e difundida, tornando-se uma concepção hegemônica.

O papel político da epistemologia é condição prévia para a efetivação de seu compromisso maior: elaborar ações que promovam o rompimento de uma visão de mundo fragmentada e acrítica dos oprimidos, objetivando a construção de uma nova realidade em que esses sujeitos possam intervir.

A ação de intervir na realidade remete a necessidade de desmitologizá-la, pois essa, em geral, está impregnada pela ideologia da classe dominante, a classe opressora. Na obra Ação cultural para a liberdade e outros escritos, Freire (2011) contempla a importância do método de alfabetização de adultos, ao problematizar que a consciência de um projeto de vida e o processo pelo qual se busca sua concretização constituem a base da ação dos seres humanos.

$\mathrm{Na}$ obra freiriana, os conceitos de ação e reflexão estão imbricados e o processo de alfabetização, como ação cultural para a liberdade, é “[...] um ato de conhecimento em que os educandos assumem o papel de sujeitos cognoscentes em diálogo com o educador, sujeito cognoscente também" (FREIRE, 2011, p. 76).

Daí que o processo visa à “[...] desmitologização da realidade” (FREIRE, 2011, p. 77), na qual o sujeito tomará distância da realidade em que se encontra, para constituir o movimento de inserção crítica nessa mesma, resultando na ação sobre essa realidade 
constituída. Para além de resultar uma forma de linguagem, o processo busca desvelar as relações dos sujeitos com o mundo, como modo de ação política, pela consciência de si.

A análise dessas relações passa a aclarar o movimento dialético que há “[...] entre os produtos que os seres humanos criam ao transformarem o mundo e ao condicionamento que esses produtos exercem sobre eles" (FREIRE, 2011, p. 78). De mesma maneira, esse aclarar acontece também em relação à ação, a prática, na construção do conhecimento e, em consequência, a reflexão crítica sobre a prática.

Nesse contexto, irá formar-se a oportunidade para que os envolvidos na relação compreendam o que significa dizer a palavra, relacionando o ato de tranformar o mundo ao ato de pronunciá-lo, pois não há pronúncia do mundo se não existir a consciente ação transformadora sobre esse.

Dizer a palavra, na proposta freiriana é o direito do ser humano de expressar-se e expressar o mundo, de exercer decisões e fazer opções. Tal situação, em uma sociedade de classes, remete a adoção por parte da classe dominante da chamada cultura do silêncio em que essa cultura não permite a expressão autêntica, limitando e cerceando o ser humano.

Na obra Pedagogia do Oprimido, quando Freire (2004) remete ao direito de dizer a palavra, o faz no sentido de enfatizar que o ato de dizer a palavra verdadeira seja o de transformar o mundo, pressupostos esses imbricados ao conceito de práxis, como ação e reflexão, situadas por argumentos da educação libertadora.

O mesmo autor argumenta que o ser humano, pela sua própria condição existencial, é aquele que deve pronunciar ${ }^{6}$ e modificar o mundo. É nessa compreensão que "[...] o mundo pronunciado, por sua vez, se volta problematizado aos sujeitos pronunciantes, a exigir deles novo pronunciar" (FREIRE, 2004, p. 78, grifo do autor).

As ações de pronunciar e modificar o mundo constituem-se como direito de todos os seres humanos, não como privilégio de alguns, de tal maneira que ninguém deva dizer a palavra verdadeira sozinha ou dizer para os outros, mas pronunciá-la na relação de partilha com os outros.

Essa é a razão que remete à impossibilidade do diálogo entre o que desejam a pronúncia da palavra verdadeira e os que não a querem ou, de outra maneira, "[...] entre os que negam aos demais o direito de dizer a sua palavra e os que se acham negados deste direito" (FREIRE, 2004, p. 79).

${ }^{6} \mathrm{Na}$ obra Pedagogia do oprimido, Freire (2004) elabora a diferença entre o dizer e o pronunciar. No caso, o dizer a palavra sozinho ou aos outros, como ato prescritivo, é como roubar a palavra aos demais. O autor enfatiza que o diálogo é o encontro dos seres humanos "[...] mediatizados pelo mundo, para pronunciá-lo, não se esgotando, portanto, na relação eu-tu” (FREIRE, 2004, p. 78). 
Ao pronunciar o mundo, pela palavra verdadeira, os sujeitos transformam e humanizam esse mesmo mundo, e o diálogo passa a constituir-se como caminho para que os envolvidos ganhem significação enquanto seres. É a partir desses pressupostos que o diálogo torna-se fundamento como ato colaborativo dos seres humanos, no momento em que se problematiza o mundo em prol da libertação desses sujeitos.

\section{O diálogo em uma educação como ato político}

Tendo como foco a problemática da educação e da alfabetização de adultos, Freire demonstra sua preocupação no intuito de superar as injustiças sociais, tendo como foco a transformação da sociedade. Segundo Calado (2001), a educação “[...] aí se insere como ferramenta, certamente necessária e altamente relevante, mas não suficiente em si mesma" (CALADO, 2001, p. 57).

A argumentação do autor está embasada na discussão de que, associada aos discursos, a mudança, para acontecer, demanda que os sujeitos assumam-se como protagonistas da própria libertação, tarefa essa, não raro, dificultada pelas situações da cotidianidade.

Tem-se como intencionalidade problematizar os diálogos de Freire com os camponeses chilenos e trabalhadores da Zona da Mata, descritos na obra Pedagogia da esperança: um reencontro com a pedagogia do oprimido, para além de considerá-los como motivadores da aprendizagem, mas diálogos nos quais os sujeitos sejam como autores de processos de tomada de consciência articulados à educação, inseridos em propostas de ação sobre a realidade constituída. O objetivo é desvelar como, nessas relações, os sujeitos se apropriam dos saberes em relação ao contexto vivido.

O diálogo freiriano, com os camponeses, parte de uma reflexão na qual, por meio da dialética e da maiêutica ${ }^{7}$, elabora-se o perguntar no intuito de refutar a tese contrária pela contradição, preparando o novo argumento. Para Calado (2001), há uma influência do pensamento socrático na filosofia freiriana, principalmente, em relação ao autoconhecimento e aprofundamento introspectivo da condição humana.

Procurando uma aproximação à proposta socrática, infere-se como ponto em comum a sistematização da dúvida, quando, por análises e sínteses, é possível exercer provocações sobre as questões em discussão, no intuito de fazer surgirem novos saberes.

\footnotetext{
${ }^{7}$ A maiêutica propõe ao sujeito descobrir gradativamente o conhecimento sobre o objeto de discussão. Para Japiassu e Marcondes (2001), a maiêutica consiste em um procedimento no qual Sócrates, “[...] partindo das opiniões que seu interlocutor tem sobre algo, procura fazê-lo cair em contradição ao defender seus pontos de vista, vindo assim a reconhecer sua ignorância acerca daquilo que julgava saber" (JAPIASSU; MARCONDES, 2001, p. 123). Desse modo, a partir do reconhecimento da ignorância, passa-se a descobrir, pela razão, a verdade.

RPGE- Revista on line de Política e Gestão Educacional, Araraquara, v.22, n.1, p. 365-380, jan./abr. $2018 \quad$ ISSN: 1519-9029 DOI: 10.22633/rpge.v22.n.1.2018.10707 
Os relatos em Freire (2002) são extraídos, primeiramente, de uma visita do autor a um assentamento da reforma agrária, distante de Santiago, no Chile e, posteriormente, com trabalhadores no corte da cana no Brasil, especificamente no estado de Pernambuco. Os círculos de cultura ${ }^{8}$ constituídos tornaram-se os momentos nos quais Freire se propôs acompanhar o processo de leitura da palavra e de releitura de mundo.

Ao iniciar o diálogo com o grupo de campesinos, no Chile, mesmo que, de modo geral, Freire evitasse fazê-lo por causa da língua, o pedagogo solicitou licença ao educador que coordenava a discussão do grupo, perguntando a esse se aceitava uma conversa. Nas palavras do autor: "Depois da aceitação, começamos um diálogo vivo, com perguntas e respostas de mim e deles a que, porém, se seguiu, rápido, um silêncio desconcertante" (FREIRE, 2002, p. 46).

A intencionalidade freiriana constitui-se em resgatar a história dos sujeitos envolvidos na discussão. As colocações do autor criam espaços para uma atividade preliminar no que trata a ação de aproximar e conhecer os sujeitos, proporcionando uma atmosfera de proximidade entre esses. Nessa relação, o sujeito se constitui com o outro, com identidade, e não como um desconhecido.

Na sequência, surge o questionamento de um camponês: “'Desculpe, senhor', disse um deles, 'que estivéssemos falando. O senhor é que podia falar porque o senhor é o que sabe. Nós, não'" (FREIRE, 2002, p. 46, grifo do autor).

Freire percebe a exigência de seu interlocutor, mas nega a preleção com o intuito de reforçar uma ideologia já explicitada. Pelo contrário, propõe a compreensão a partir da aceitação de algo argumentado no discurso do camponês, problematizando-o e trazendo-o ao diálogo.

\begin{abstract}
"Muito bem", disse em resposta à intervenção do camponês. "Aceito que eu sei e vocês não sabem. De qualquer forma, gostaria de lhes propor um jogo que, para funcionar bem, exige de nós absoluta lealdade. Vou dividir o quadro-negro em dois pedaços, em que irei registrando, do meu lado e do lado de vocês, os gols que faremos eu, em vocês; vocês, em mim. O jogo consiste em cada um perguntar algo ao outro. Se o perguntado não sabe
\end{abstract}

${ }^{8} \mathrm{O}$ círculo de cultura traduz para a educação uma forma organizacional para trabalhos em grupos, na qual há uma hierarquia de importância para as pessoas envolvidas. O educador é visto como coordenador ou monitor do processo ensino aprendizagem tal que a proposta preconiza uma igualdade de participações. Freire (1980) enfatiza a importância dos círculos como momentos nos quais é possível discutir, organizar e planificar ações no coletivo. Os círculos de cultura remetem às experiências de Paulo Freire no Movimento de Cultura Popular em Recife, PE, no Projeto de Educação de Adultos, entre os anos 50 e 60. No círculo de cultura, em "[...] lugar do professor, com tradições fortemente 'doadoras', o Coordenador de Debates. Em lugar de aula discursiva, o diálogo. Em lugar de aluno, com tradições passivas, o participante de grupo. Em lugar dos 'pontos' e de programas alienados, programação compacta, 'reduzida'e 'codificada' em unidades de aprendizado" (FREIRE, 1969, p. 103, grifo do autor). 
responder, é gol do perguntador. Começarei o jogo fazendo uma primeira pergunta a vocês. (FREIRE, 2002, p. 48).

Para Freire (2002), ensinar e aprender representam momentos de um processo maior, ou seja, o de conhecer, o qual implica reconhecer, pois " [...] o educando se torna realmente educando quando e na medida em que conhece, ou vai conhecendo os conteúdos, os objetos cognoscíveis, e não na medida em que o educador vai depositando nele a descrição dos objetos, ou dos conteúdos" (FREIRE, 2002, p. 47).

$\mathrm{Na}$ sequência, Freire assume o jogo com o grupo, iniciando os questionamentos: “Que significa a maiêutica socrática? Gargalhada geral e eu registrei o meu primeiro gol. Agora cabe a vocês fazer a pergunta a mim - disse. Houve uns cochichos e um deles lançou a questão: - Que é curva de nível? Não soube responder. Registrei um a um” (FREIRE, 2002, p. 48). Dessa forma, o autor segue o diálogo:

- Qual a importância de Hegel no pensamento de Marx? Dois a um. - Para que serve a calagem do solo? Dois a dois. - Que é um verbo intransitivo? Três a dois. - Que relação há entre curva de nível e erosão? Três a três. Que significa epistemologia? Quatro a três. - O que é adubação verde? Quatro a quatro. Assim, sucessivamente, até chegarmos a dez a dez (FREIRE, 2002, p. 48).

Freire sugere aos camponeses a reflexão sobre o acontecido: inicialmente à discussão, segue-se o silêncio e, finalmente, o jogo. A discussão pela novidade no círculo de cultura, como momento de aproximação dos sujeitos; o silêncio, por apontar o autor como um sábio a fazer uma preleção e, por fim, o jogo, pela ironia em trabalhar o conhecimento.

O relato na obra freiriana aponta para outro diálogo ocorrido na Zona da Mata, em Pernambuco, anterior ao período de exílio de Paulo Freire. Diálogo muito semelhante ao dos camponeses chilenos, o qual inicia com o seguinte questionamento: “- Eu sei. Vocês não sabem. Mas por que eu sei e vocês não sabem?” (FREIRE, 2002, p. 49).

Freire propõe uma aprendizagem a partir do diálogo e, contrário às preleções e conferências, constitui seu modo de educar. Assim, o autor exercita, vagarosamente, a reflexão com o objetivo de construir um saber.

Retomando o diálogo, Freire claramente tem por objetivo sua intervenção. Rapidamente, surge a resposta: “- O senhor sabe porque é doutor. Nós, não” (FREIRE, 2002, p. 49). Freire segue o diálogo:

- Exato, eu sou doutor. Vocês não. Mas, por que eu sou doutor e vocês não? - Porque foi à escola, tem leitura, tem estudo e nós, não. - E por que fui à escola? - Porque seu pai pôde mandar o senhor à escola. O nosso, não. - E 
por que os pais de vocês não puderam mandar vocês à escola? - Porque eram camponeses como nós. - E o que é ser camponês? - É não ter educação, posses, trabalhar de sol a sol sem direitos, sem esperança de um dia melhor. - E por que ao camponês falta tudo isso? - Porque Deus quer (FREIRE, 2002, p. 49).

Para Freire, os camponeses estavam tentando superar a relação proposta na obra Pedagogia do oprimido, no momento em que se constitui a aderência do oprimido ao opressor, fazendo, em um segundo instante, com que se tome distância do opressor para permitir localizá-lo fora de si próprio.

- E quem é Deus? - É o Pai de nós todos. - E quem é pai aqui nesta reunião? Quase todos de mão para cima, disseram que o eram. Olhando o grupo todo em silêncio, me fixei num deles e lhe perguntei: - Quantos filhos você tem? - Três. - Você seria capaz de sacrificar dois deles, submetendo-os a sofrimentos para que o terceiro estudasse, com vida boa, no Recife? Você seria capaz de amar assim? - Não! - Se você - disse eu -, homem de carne e osso, não é capaz de fazer uma injustiça desta, como é possível entender que Deus o faça? Será mesmo que Deus é o fazedor dessas coisas? Um silêncio diferente, completamente diferente do anterior, um silêncio no qual algo começava a ser partejado. Em seguida: - Não. Não é Deus o fazedor disso tudo. É o patrão! (FREIRE, 2002, p. 49-50).

Nos movimentos realizados, é possível identificar o opressor. A partir dessa ideia, o oprimido compreende o papel do patrão, inserido no sistema socioeconômico e político, problematizando as relações sociais de produção e os interesses de classe.

Assumindo, como foco, as relações educativas, Freire afirma que viver, enquanto educador, significa reconhecer nos outros o direito de dizer a sua palavra, direito de alguém falar ao que corresponde, de igual forma, o dever da escuta.

O diálogo constitui-se como articulador do entendimento entre os sujeitos, proporcionando um exercício entre iguais e diferentes, no qual é permitido ouvir o outro, com alteridade, um diálogo fundamentado na humildade, em detrimento da autonomia, pois não há diálogo se não existe humildade.

Aproximam-se as ideias de Ghiggi (2010), quando o autor argumenta que, dentre as categorias elaboradas por Freire, as quais ganham centralidade na revivificação da educação popular, está o diálogo. "Diálogo, que se realiza na dimensão política da educação, ou seja, que parte da situação concreta, que repensa a prática e que institui processos de transformação" (GHIGGI, 2010, p. 114).

O mesmo autor, considerando o olhar sobre a educação popular, advoga que o diálogo toma, como ponto de partida, o quadro antropológico-cultural, o qual está, intimamente, 
ligado à vida de quem participa da relação educativa, na qual o universo temático, como o mundo da cultura dos sujeitos envolvidos, permite a construção do universo vocabular.

O diálogo permite, a partir de sua dimensão ontológica, que a partilha entre educador e educandos ganhe centralidade, redefinindo o quadro do poder entre os sujeitos envolvidos. A partir dessa discussão, Ghiggi (2010) reafirma que Freire não acatava a cartilha ${ }^{9}$ pronta, aceitando o desafio de construí-la, pressuposto esse o qual define o nascimento e importância da relação dialógica no pensamento freiriano.

Com esse intuito, Freire dedica-se à escrita dos Cadernos de Cultura, obra na qual o conceito de cultura está enraizado ao antropológico, “[...] reconhecendo a possibilidade dos seres humanos exercerem papel ativo na relação com suas realidades, quando as ideias e os atos são produções culturais e não elementos estranhos ao ser humano" (GHIGGI, 2010, p. 113).

A partir dessas ideias, na relação dialógica, a compreensão do mundo para a sua transformação ganha centralidade, mas, ao mesmo tempo, compreende-se o alerta da proposta freiriana quanto a existência de um quadro perverso do poder, instituído na luta de classes, fazendo necessário que se fundamente "[...] o exercício da diretividade e da autoridade em educação, para que a educação parta, sempre, do mundo da vida das pessoas" (GHIGGI, 2010, p. 114).

Isso não quer dizer que se abra mão dos conteúdos programáticos, mas sustenta-se que o ensinar e o aprender fazem parte do mesmo processo de conhecer, e que o pressuposto diferencial é o ensinar como conhecer.

Nessa linha de discussão, tendo o diálogo como pressuposto ontológico, Freire (1991) argumenta que é tarefa do educador testemunhar aos educandos "[...] como você estuda, como você se aproxima do objeto de seu conhecimento, o que significa para você a busca do conhecimento" (FREIRE, 1991, p. 115).

A afirmação demonstra a contrariedade do autor ao discurso conceitual do objeto em questão, em detrimento do exercício do como conhecer. É partindo do mundo da vida e pela relação dialógica que Freire irá desafiar os seres humanos a uma compreensão da realidade

${ }^{9}$ Ghiggi (2010) afirma que Paulo Freire, entre os anos 50 e 60, atuando no Movimento de Cultura Popular em Recife, PE, elabora um amplo estudo das cartilhas em circulação. "Nelas encontra sentenças culturais, antropológicas, epistemológicas e éticas não condizentes com a visão de mundo e de humano que o seu tempo indicava necessárias para dar conta das imperativas mudanças” (GHIGGI, 2010, p. 113). Na obra Educação como prática da liberdade, Freire (1969) demonstra sua descrença nas cartilhas quando afirma que "[...] essas pretendem a montagem da sinalização gráfica como uma doação e reduzem o analfabeto à condição de objeto que à de sujeito de sua alfabetização" (FREIRE, 1969, p. 111, grifo do autor). Para o mesmo autor, o fundamental na alfabetização, em uma língua silábica, é que o ser humano possa apreender criticamente o seu mecanismo de formação vocabular, para que ele mesmo faça o jogo criador das combinações.

RPGE- Revista on line de Política e Gestão Educacional, Araraquara, v.22, n.1, p. 365-380, jan./abr. $2018 \quad$ ISSN: 1519-9029 DOI: $10.22633 /$ rpge.v22.n.1.2018.10707 
constituída, na qual o aprendizado, pela busca desse conhecimento, ganha centralidade. $\mathrm{O}$ contrário, simplesmente, o ato de transmitir esse mesmo conhecimento é impeditivo ao desenvolvimento do pensamento freiriano.

\section{Educação como ato político}

Na concepção freiriana, a educação como ato político é aquela que permite que os sujeitos busquem outros projetos de vida, em uma perspectiva libertadora, a qual está fundamentada na luta pela construção de alternativas para as transformações sociais. Essa mesma educação, não neutra, compreende a existência de projetos sociais, econômicos e políticos em permanente disputa pela sociedade.

Nessas condições, retoma-se a importância do diálogo como momento para que os seres humanos exerçam o direito de dizer a palavra verdadeira ou, ainda, possam pronunciar o mundo. Ao mesmo tempo reconhe-se a necessidade de aclarar a opção que se faz em defesa de um projeto e não de outro.

Na obra A importância do ato de ler: em três artigos que se completam, Freire (1983), no momento em que discute a alfabetização de adultos e a criação de bibliotecas populares ${ }^{10}$, reflete que a finalidade da leitura e da escrita não está fundamentada em si, pois o ler e o escrever implicam atividades para além do simples ato mecânico no qual o ser humano possa constituir uma compreensão crítica da realidade.

Problematizando sobre a atividade de alfabetização, retoma a questão do mito da neutralidade da educação, a qual, se tratada como neutra, meramente mecânica e dissociada da realidade, nega a natureza política do processo educativo, servindo a um modelo de abstração do ser humano.

Por outro lado, a prática crítica compreende de modo articulado a natureza política do processo educativo e o caráter educativo do ato político, mas isso não esgota a compreensão de ambos.

É nesse sentido que a prática política constitui-se a partir da significação educativa, quando todo partido político faz-se educador no momento em que sua proposta toma proporções nos atos de denúncia e anúncio. Do mesmo modo, o processo educativo não

10 Alfabetização de adultos e bibliotecas populares - uma introdução é uma palestra apresentada no XI Congresso Brasileiro de Biblioteconomia e Documentação, realizado em João Pessoa, PB, em janeiro de 1982. O texto está disponível na obra A importância do ato de ler: em três artigos que se completam, conforme já referenciado. 
neutro, a serviço da libertação dos seres humanos, constitui-se a partir da compreensão crítica da realidade em um dado momento histórico.

A questão fundamental referida por Freire organiza-se em torno de: “[...] a favor de quem e do que, portanto contra quem e contra o que, fazemos a educação e de a favor de quem e do que, portanto contra quem e contra o que, desenvolvemos a atividade política" (FREIRE, 1983, p. 27, grifo do autor).

Quanto mais se compreende a relação entre a natureza política do processo educativo e o caráter educativo do ato político, maior é a percepção da impossibilidade de separação entre esses. É fundamentado nessas condições que Freire remete à questão do poder ${ }^{11}$, argumentando que a educação forma relações dinâmicas, contraditórias, e não mecânicas, com um sistema maior.

São essas relações dinâmicas e contraditórias que permitem pensar a educação, mesmo como parte de um sistema maior, para além da simples reprodução da ideologia dominante, uma vez que essas contradições as quais caracterizam a sociedade contemporânea tomam conta das instituições onde a educação sistemática está acontecendo e acabam por alterar o papel reprodutor da própria ideologia dominante.

A percepção da inviabilidade de uma educação neutra ocorre na medida em que se compreende a relação dialética na qual, de um lado, reproduz-se a ideologia dominante e, do outro, nega-se essa mesma, pelo confronto entre a primeira e a realidadade vivida pelos educadores e educandos.

A proposta freiriana alerta ao educador sobre o erro de, ao negar a neutralidade no processo educativo, tornar-se manipulador, visto que a prática libertadora não se realiza, nem pela manipulação, nem pela espontaneidade. "A manipulação é castradora, por isso autoritária. O espontaneísmo é licencioso, por isso irresponsável” (FREIRE, 1983, p. 29).

A partir desse momento, Freire remete à necessidade de que o educador venha a aclarar a sua opção, a qual é política e deverá manter coerência na prática. A coerência entre a opção política e a prática é uma exigência pessoal e enfatiza-se que “[...] não é o discurso o que ajuíza a prática, mas a prática que ajuíza o discurso" (FREIRE, 1983, p. 29).

${ }^{11}$ Com o intuito de exemplificar a questão do poder, a partir da relação entre a natureza política do processo educativo e o caráter educativo do ato político, Freire (1983) utiliza o exemplo da classe burguesa, quando afirma que não foi a própria educação burguesa "[...] que criou ou enformou a burguesia, mas a burguesia que, chegando ao poder, teve o poder de sistematizar a sua educação. Os burgueses, antes da tomada do poder, simplesmente, não poderiam esperar da aristocracia no poder que pusesse em prática a educação que lhes interessava" (FREIRE, 1983, p. 27). Por outro lado, a educação burguesa começou a se constituir, historicamente, antes mesmo da tomada do poder pela burguesia. "Sua sistematização e generalização é que só foram viáveis com a burguesia como classe dominante e não mais contestatória" (FREIRE, 1983, p. 28).

RPGE- Revista on line de Política e Gestão Educacional, Araraquara, v.22, n.1, p. 365-380, jan./abr. $2018 \quad$ ISSN: $1519-9029$ 
Surge o problema no momento em que o educador proclama uma opção democrática e acaba por desenvolver uma prática não coerente com o discurso. Daí que esse discurso seja um palavreado composto de vocábulos inflamados e contraditos, remetendo a manter uma prática autoritária a qual mesmo com um discurso democrático acaba por negar o direito dos sujeitos para que pronunciem a sua palavra. De outra maneira, a prática democrática significa reconhecer que os outros possuem o direito de dizer a sua palavra.

Uma prática democrática constitui-se quando o direito de falar corresponde ao dever de escutar, e como escutar implica falar, o dever de escutar corresponde ao direito, igualmente, de falar a quem se escuta. Dessa maneira, o escutar é falar com os seres humanos envolvidos na relação, enquanto que o simplesmente falar seria uma forma de não os ouvir.

Quando a opção do educador é libertadora, o processo educativo torna-se um ato de dizer a palavra, expondo-se a palavra dos outros sujeitos. Já quem fala e jamais ouve, segundo Freire, imobiliza o conhecimento e o transfere aos educandos, não reconhecendo a possibilidade de os sujeitos reivindicarem seus direitos, colaborando para a preservação das estruturas opressoras.

Nesses movimentos de ouvir e falar, é importante estar atento aos níveis de compreensão dos educandos em relação à realidade, pois, não raro, ocorre uma compreensão menos rigorosa do contexto por parte desses sujeitos. "Impor a eles a nossa compreensão em nome da sua libertação é aceitar soluções autoritárias como caminhos de liberdade" (FREIRE, 1983, p. 31).

Daí que a proposta freiriana compreende que assumir a ingenuidade dos educandos demanda do educador a humildade necessária para assumir a criticidade, superando a própria ingenuidade. De maneira contrária, o autoritário, aquele educador que nega a solidariedade na relação educativa, principalmente no ato de ser educado pelo educando, separa o ato de ensinar do ato de aprender.

Para esse educador compreende-se que é preciso reconhecer os educandos como sujeitos no processo da construção do saber e não, apenas, como seres acomodados a uma situação, bem como, reconhecer que o conhecimento está para além de um dado concluído, transferido por alguém que o adquiriu para outro que ainda não o possui.

Aceitar o processo educativo como um quefazer puro, crendo na neutralidade da educação, o educador reforçará uma visão ingênua dessa, na qual o ser humano assume uma conotação abstrata, mantendo, quando muito, obras assistenciais e humanitárias a favor de um sistema maior. De mesma maneira, a visão ingênua propõe que o processo educativo 
proporcione “[...] carne e espírito ao modelo de ser humano virtuoso que, então, instaurará uma sociedade justa e bela" (FREIRE, 1983, p. 33).

Retoma-se a importância de que o educando esteja inserido no processo educativo, em um processo criador, no qual se constitui como sujeito. Quando Freire reflete sobre o rótulo atribuído ao analfabeto, o faz questionando o caráter mágico da palavra escrita, vista como se fosse uma palavra salvadora ${ }^{12}$, a qual remete esse ser a uma condição de passividade.

A prática democrática e crítica, pelo contrário, mantém correlacionada a leitura do mundo a leitura da palavra, como leitura da realidade, na qual o sujeito atuará sobre essa, de forma a propor transformações. Ao mesmo tempo, a leitura do real não deve ser a repetição mecância da leitura feita pelo educador, mas relacionada à experiência comum dos educandos a partir de suas palavras e temas significativos.

Nessa esteira, Freire remete a pensar que, em um primeiro momento, os textos oferecidos aos sujeitos mais escondiam do que, propriamente, desvelavam a realidade, mas "[...] agora, pelo contrário, a alfabetização como ato de conhecimento, como ato criador, e como ato político é um esforço de leitura do mundo e da palavra" (FREIRE, 1983, p. 33, grifo nosso).

\section{Considerações Finais}

A educação libertadora está a serviço das classes dominadas como prática social e constitui-se como uma educação política. Tão política quanto a que serve à ideologia da classe dominante e a proclama como neutra. A diferença está no processo de transformação social, conforme previsto na primeira, para colocá-la em prática, em termos sistemáticos.

Para Freire seria uma ingenuidade que as classes oprimidas esperassem das classes dominantes a prática de uma educação que desvelasse as contradições em que se encontravam. A classe oprimida, pela sua própria experiência e pelo novo aprendizado, vai criando uma visão cada vez mais clara de sua realidade histórica, a qual, associada ao descobrimento de novas formas de ação, menos assitencialistas, transforma essa realidade.

Considerando as ideias descritas, compreende-se a articulação do pensamento freiriano com a práxis social. Práxis que parte da realidade, do contexto histórico no qual o ser humano está inserido e, por movimentos de percepção crítica dessa mesma realidade, realiza

12 A reflexão de Freire (1983) remete àqueles que consideram o analfabeto como um "homem perdido", fora da realidade. Nessa perspectiva é preciso salvar esse ser humano e sua salvação está no ato de receber a palavra de maneira passiva. "Daí que o papel de analfabeto não seja o de sujeito de sua própria alfabetização, mas o de paciente que se submete docilmente a um processo em que não tem ingerência” (FREIRE, 1983, p. 33).

RPGE- Revista on line de Política e Gestão Educacional, Araraquara, v.22, n.1, p. 365-380, jan./abr. $2018 \quad$ ISSN: 1519-9029 
movimentos de reflexão. Essa reflexão, imbricada ao processo de conscientização, proporcionará novas ações de transformação.

No intuito de finalizar o texto, aproximando-o ao tema discutido, elencam-se ideias as quais possuem por objetivo promover relações educativas nas quais se façam presentes os movimentos de ação-reflexão. Nesse sentido, compreende-se:

a) A práxis como a relação entre o modo de compreender criticamente a realidade e a prática que decorre dessa compreensão, a qual levará a uma ação transformadora - o exercício da práxis, a qual exige ação-reflexão, irá movimentar o educador no sentido de estar aberto à percepção dos saberes socializados pelos educandos, sua problematização e possíveis ações de transformação;

b) A não neutralidade nas relações educativas - o processo educativo neutro está a favor dos interesses da classe dominante, mas o educador o qual endossa a ideia de não neutralidade está a favor de constituir uma leitura de vida, crítica e ética, em favor dos educandos e de seu contexto; e

c) A perscpectiva progressista crítica, na qual os educandos são convidados a pensar, como seres que sabem o que conhecem, envolvidos na compreensão crítica da realidade - o educador que se percebe como aprendente é aquele que se coloca em posição de facilitador da reflexão e compreensão dos saberes dos educandos.

Partindo dos pressupostos aqui explicitados, reflete-se que a obra de Paulo Freire representa um marco conceitual capaz de sustentar a formação dos seres humanos, formação essa imbricada a transformação social, tal que a apreensão das determinantes históricas seja o foco dessa formação, como facilitador, assim, do envolvimento dos sujeitos nos movimentos de ação-reflexão.

\section{REFERÊNCIAS}

ANDREOLA, B. Mundo. In: STRECK, Danilo.; REDIM, Euclides.; ZITKOSKI, Jaime Jose (orgs). Dicionário Paulo Freire. 2. ed. Belo Horizonte: Autêntica, 2010. p. 282-283.

CALADO, A. J. F. Paulo Freire: sua visão de homem, de homem e de sociedade. Caruaru: FAFICA, 2001.

FREIRE, P. Educação como prática da liberdade. 2. ed. Rio de Janeiro: Paz e Terra, 1969.

FREIRE, P. Quatro cartas aos animadores de Círculos de Cultura de São Tomé e Príncipe. In: BEZERRA COSTA, M. A.; BRANDÃO, C. R. (Orgs). A questão política da educação popular. São Paulo: Brasiliense, 1980. p. 136-195. 
FREIRE, P. A importância do ato de ler: em três artigos que se completam. 3. ed. São Paulo: Cortez, 1983.

FREIRE, P. A educação na cidade. São Paulo: Cortez, 1991.

FREIRE, P. Pedagogia da esperança: um reencontro com a pedagogia do oprimido. 9. ed. Rio de Janeiro: Paz e Terra, 2002.

FREIRE, P. Pedagogia do oprimido. 38. ed. São Paulo: Paz e Terra, 2004.

FREIRE, P. Ação cultural para a liberdade e outros escritos. 14. ed. Rio de Janeiro: Paz e Terra, 2011.

GHIGGI, G.; Paulo Freire e a revivificação da educação popular. Educação. Porto Alegre, v. 33, n. 2, p. 111-118, maio/ago., 2010.

JAPIASSU, H.; MARCONDES, D. Dicionário básico de filosofia. 3. ed. Rio de Janeiro: Jorge Zahar, 2001.

KRONBAUER, L G. Ação-reflexão. In: STRECK, D.; REDIM, E.; ZITKOSKI, J. J. (Orgs). Dicionário Paulo Freire. 2. ed. Belo Horizonte: Autêntica, 2010. p. 23-24.

\section{Como referenciar este artigo}

FREITAS, André Luís Castro de.; FREITAS, Luciane Albernaz de Araújo. A Construção do Conhecimento a partir da realidade social do educando. Revista on line de Política e Gestão Educacional, Araraquara, v.22, n.1, p. 365-380, jan./abr., 2018 ISSN: 1519-9029. DOI: 10.22633/rpge.v22.n.1.2018.10707

Submetido em: $27 / 11 / 2017$

Aprovado em: 26/03/2018 